УДК $811 ' 111$

DOI https://doi.org/10.26661/2414-1135-2021-81-1-30

\title{
ЛІНГВОСЕМІОТИЧНИЙ БАЗИС АНГЛОМОВНОГО ДИГІТАЛЬНОГО ДИСКУРСУ ТА ТЕКСТОПРОСТОРУ
}

\author{
Лазебна Н. В. \\ кандидат філологічних наук, дочент, \\ дочент кафедри теорії та практики перекладу \\ Національний університет «Запорізька політехніка» \\ вул. Жуковського, 64, Запоріжжя, Украӥна \\ orcid.org/0000-0001-5886-693X \\ natalialazebnaya@gmail.com
}

\author{
Ключові слова: \\ англомовний дигітальний \\ дискурс / текстопростір, \\ мови програмування, \\ лінгвосеміотичний \\ базис, дискурс, текст, \\ соиіодигіталізація.
}

У статті розглядаються сучасні лінгвістичні погляди на співвідношення дискурсу до когнітивно-комунікативної діяльності. Здійснено аналіз зв'язку понятійних категорій, таких як дискурс, текст та англомовний дигітальний дискурс (АДД), який визначається як письмовий процес і результат взаємодії учасників комунікації, опосередкованої комп'ютерними технологіями, або тематично 3 ними співвіднесеними текстами на МП та їхнім лінгвосеміотичним базисом, режимами їх кодування - декодування у процесі комунікації «людина - людина», «людина - машина», «людина - машина - людина» та їхніх варіацій. Центральним поняттям дослідження $є$ «англомовний дигітальний текстопростір» (АДТП), котрий визначається як письмовий результат взаємодії учасників АДД, відображений у текстах, які опосередковують комунікацію «людина - людина», «людина - машина», «людина машина-людина» таїх варіацій. АДТПбезпосередньо або опосередковано представлений лінгвосеміотичним базисом мов програмування (МП), англомовним базисом і прописаними режимами його кодування декодування. Текст як похідна одиниця повідомлення передається під час мовленнєвого акту як самостійний об'єкт дослідження прагмалінгвістики. Тактики та стратегії подання інформації в АДД зосереджуються на увазі адресата до певної інформації та необхідним постає питання постановки чіткого завдання команд, їх детального прописування й ідентифікації алгоритмів для машин, однак мовне повідомлення людини має також вдосконалюватися лінгвальними засобами англійської мови. АДТП визначається взаємодією людини та машини. Отже, поняття «текст» виступає мовним відображенням наукової абстракції, типових властивостей різних комунікативних ситуацій, репрезентованих у межах АДД. АДТП є більш вдалим лінгвосеміотичним варіантом, утворюючи спеціальний «машинний код». Чіткий англомовний виклад інструкцій для користувачів МП, опис певних кодів об'єктно-орієнтованими МП та їх вербалізація засобами англійської мови свідчить про розширення меж такого інформаційного та технократичного простору. 


\title{
LINGUISTIC AND SEMIOTIC BASIS OF ENGLISH-LANGUAGE DIGITAL DISCOURSE AND TEXTUAL SPACE
}

\author{
Lazebna N. V. \\ Candidate of Philological Sciences, Associate Professor, \\ Associate Professor at the Department of Theory and Practice of Translation \\ "Zaporizhzhia Polytechnic" National University \\ Zhukovskoho str., 64, Zaporizhzhia, Ukraine \\ orcid.org/0000-0001-5886-693X \\ natalialazebnaya@gmail.com
}

Key words: English-language digital discourse / textual space, programming languages, linguosemiotic basis, discourse, text, social digitalization.
The article considers discourse via cognitive-communicative activities of humans. The analysis focuses on the relationship of discourse, text and English-language digital discourse (ElDD). The latter (ElDD) is defined as a written process and the result of participants' interaction mediated by computer technology, or thematically related texts written on programming languages (PLs) and their linguosemiotic basis, and modes of their encoding - decoding in the process of communication "human - human - machine", "human - machine - human" and their variations. The central concept of the study is "English-language digital textual space" (ElDTP), which is defined as a written result of the participants' interaction, reflected in the texts that mediate communication "human - human", "human - machine", "human - machine - human" and their variations. EIDTP is directly or indirectly represented by the linguosemiotic basis of programming languages (PLs), the English-language basis, and the prescribed modes of its encoding-decoding. Tactics and strategies for representing information in EIDD focus on the addressee's attention to certain information and requires setting of a clear task for Pls commands, their clear verbalization and identification of algorithms for machines. However, human communication modes with the machine must also be improved by means of the English language. ElDTP is determined by the interaction of human and machine. Thus, the concept of "text" is a linguistic reflection of scientific abstraction, representing typical features of various communicative situations within ElDD. EIDTP is a more successful linguosemiotic variant, which creates a special "machine code". A specific English-language presentation of guidelines for users of PLs, a description of certain codes by object-oriented PLs and their verbalization by means of the English language indicates the expansion of the boundaries of this informatized and technocratic verbal and creative textual space.
Постановка проблеми. Англомовний дигітальний дискурс існує переважно у формі відповідних текстів, і доцільно говорити, по-перше, про сам феномен «текст» i, по-друге, про сукупність текстів, які конституюють АДД. Таку сукупність доцільно пов'язувати 3 поняттям «текстопростір», а точніше - 3 англомовним дигітальним текстопростором (далі - АДТП). Текстопростір є виявом певної соціолінгвістичної структури, утвореної адресатами за певних умов і під впливом соціальних або прагматичних ситуацій. Ресипрокальна антропоморфність АДД («анімованість» машини) є унікальним явищем. Зміна ролей учасників комунікації (людина - машина), варіації такого типу відносин створює певну окресленість АДД.
Теза В.I. Карасика про те, що дискурс можна вивчати як із соціолінгвістичної, так і 3 прагмалінгвістичної позицій, $є$ однією 3 основних для подальшого визначення параметрів АДД. Учасники інституційного дискурсу розрізняються за своїми якостями та поведінкою. 3 одного боку, існують агенти - представники інституту (програмісти), 3 іншого - клієнти, тобто люди, котрі звертаються до агентів (користувачі). Таким чином, необхідно впровадити категорії прагмалінгвістики та теорії комунікації, що є найбільш доречними у дослідженні АДД, які будуть базовими категоріями для його подальшого аналізу [11, с. 28]. Можна виділити: учасників комунікації у таких типах відносин і їхніх варіацій: «людина 1 - програміст - машина - людина»; 
«людина-1 - людина-2 - машина - людина-1»; «людина-1 - людина у машині»; умови комунікації; організацію комунікації; способи комунікації. Унікальність англомовних текстів мов програмування (МП) у межах їх лінгвосеміотичного базису бачимо в авторстві певного медіатору. Тобто машина продукує вербокреативний текст, але його репрезентація залежить від базису, закладеного людиною.

Метою статті $\epsilon$ розмежування понять «англомовний дигітальний дискурс» і «англомовний дигітальний текстопростір». Інтегративний підхід до мов програмування (МП) та природної англійської мови П(А)М (об'скта дослідження) потребує аналізу закладеного лінгвосеміотичного базису досліджуваних мов (предмету дослідження). Аналіз основних дискурсивних і текстологічних параметрів АДД та АДТП вирішується у межах певних завдань: надати характеристики основним конституентам досліджуваних англомовних вербокреативних площин; скорелювати їх із лінгвосеміотичним базисом МП та П(А)М; охарактеризувати специфіку взаємин Людини та Машини у межах АДД; ідентифікувати механізми створення Людиною (Програмістом) коду на МП та його обробки засобами П(А)М.

Виклад основного матеріалу дослідження. 3 погляду комунікативної ситуації, в АДД необхідно виділити особистісно-орієнтовану і статусно-орієнтовану комунікацію. Перша - особливо важлива у дослідженні комунікації «Людина - Машина», коли людинаспілкуєтьсяізчат-ботом.Ї̈ікомунікація направлена на саму себе, а машина слугує лише медіатором такого типу комунікації. На підставі соціолінгвістичного підходу виділяють два основні типи дискурсу: персональний (орієнтований на особистість) та інституційний (статусно-орієнтований) $[11$, с. 6].

Персональний тип дискурсу представлений у двох різновидах - як побутове та буттєве спілкування. В.I. Карасик відзначає, що «хоча природа розширення розумінь у побутовому і буттєвому спілкуванні різна (в першому випадку усвідомлення сенсу залежить від конкретної ситуації спілкування, а у другому - від форми знака й особистісної концептосфери відправника повідомлення), особистісно-орієнтоване спілкування будується на широкому смисловому полі свідомості адресата» [11, с. 6-7].

У свою чергу, інституційний тип дискурсу $є$ спілкуванням у заданих рамках статусно-рольових відносин, тому прийнято виділяти статусно-орієнтований тип дискурсу на підставі двох системо-утворюючих ознак: цілей спілкування й учасників. Основними учасниками цього типу дискурсу є представники того чи іншого інституту (агенти) та люди, які звертаються до них (клієнти). Закономірно, що учасники інституційного дискурсу дуже відрізняються за своїми якостями та поведінкою, також існує різний ступінь відкритості дискурсу, оскільки спостерігається варіативність у характеристиках його клієнтів / агентів [22, с. 194]. В.I. Карасик вказує, що для кожного виду інституційного дискурсу характерна своя міра співвідношення між статусним і особистісним компонентами [11, с. 11-12]. Специфічність статусно-орієнтованого дискурсу розкривається в його типі, тобто в типі суспільного інституту, від імені якого його концептосфери [11, с. 12].

\section{Параметри АДД}

АДД робить простір спілкування сучасників ще більш розмаїтим, адже людина - машина можуть змінювати свої ролі та, наприклад, англовний чат-бот може бути повноцінним співрозмовником, котрий сприйматиметься як людина або як явище ще вищого рівня - соціальні агенти або анімовані машини, коли людина на екрані машини може бачити персоніфікованого робота, здатного не лише до вербального, а й до невербального способів комунікації (рис. 1).

Повертаючись до комплексної моделі вивчення дискурсу, запропонованої В.I. Карасиком, зважатимемо на виділення в іiі рамках чотирьох груп категорій дискурсу [11, с. 300]. Конститутивні категорії дискурсу включають у себе цілі, цінності та стратегії відповідного виду дискурсу, прецедентні (культурогенні) феномени. АДД володіє усім розмаїттям функціональних цілей, притаманних традиційному дискурсу: комунікативні (чат-боти, анімовані агенти), ігрові, навчальні, соціалізативні, розважальні (МП Scratch) і т. ін. Також необхідно враховувати: розробників та учасників АДД (замовників, програмістів, реципієнтів, машину або комп'ютер, чат-ботів чи інших інформаційних асистентів, котрі опосередковують комунікацію у межах АДД); загальні риси учасників АДД; тексти АДД різного

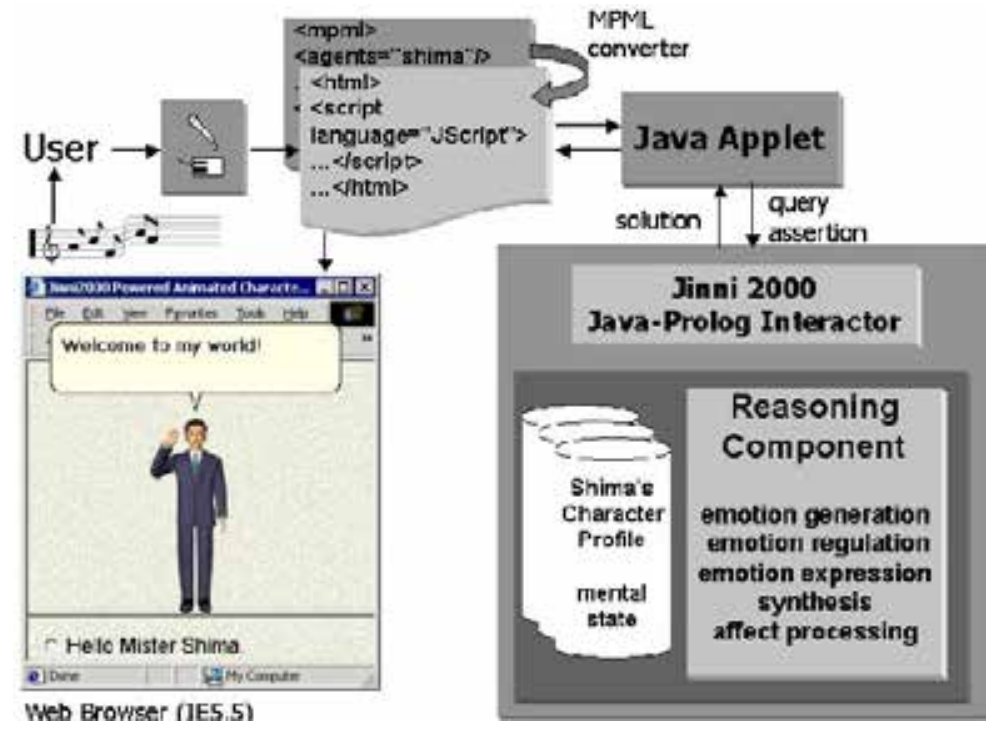

Рис. 1. Лінгвосеміотична репрезентація анімованого соціального агента 
жанру та тематики, який стосується інноваційних розробок, залучених до обговорення в АДД (робототехніка, обробка природної мови, розробка чат-ботів та ін.); вербальні та невербальні, стилістичні та синтаксичні шари АДД. Важливу роль у дискурсі відіграє певна соціальна група. Отже, дослідження їхніх мовленнєвих і лінгвальних компетенцій, їхніх комунікативних інтенцій i т. ін. $є$ релевантним для подальшого аналізу АДД. Незважаючи на різницю вікових, інтелектуальних, психологічних та інших ознак, загальною рисою соціальної групи $\epsilon$ намір впорядкування лінгвологічного та лінгвосеміотичного базису АДД та їх узагальнення (дослідження мов програмування і співвідношення із законами англійської мови) [25, с. 126].

Цілком очевидно, що комунікативною метою АДД є також і віднаходження комунікативної ланки 3 машиною (наприклад, опис команд МП англійською мовою). Можливість самовираження та пошуку однодумців у процесі комунікації із чат-ботом або груповим чат-ботом вже переступає щабель комунікації в різних інтернет-спільнотах. Людина вже чекає на схвалення та розуміння машини. Наприклад, програміст описує код на МП для користувачів і чекає на коректну роботу певної програми або груповий чат-бот виконує функцію модератора, який опосередковує комунікацію між людьми.

Комунікативною метою АДД є глобальна сойодигіталізація, що є безмежним лінгвосеміотичним континуумом, спрямованим на інтеграцію людини та машини та створення певного Human /Non-Human Symbiosis. Отже, основною цінністю $є$ перетин будьяких комунікативних меж, виражених вербально чи невербально. Необмежена доступність отримання інформації та відсутність просторових меж, розмивання відстаней і стирання обмежень між людиною та машиною є унікальними рисами АДД. Можливо також типологізувати АДД за такими параметрами: за сферою функціонування (соціально-ситуативним параметром); за сферою комунікації; за типом мовлення (каналом передачі інформації) [24, с. 15]. АДД існує у двох формах: монологічній і діалогічній. Він також $є$ різноспрямованим, оскільки може скеровувати комунікацію «людина - машина» чи «машина - людина», «людина - людина». Можна розглядати такий дискурс і $з$ позиції лінгвосеміотичної перспективи [6, с. 59; 7, с. 39].

На базисному рівні АДД слід розглядати як лінгвоматематичний конгломерат, коли кодується комунікація «людина - машина» засобами англійської мови та мовами програмування. На проміжному рiвні, у процесі комунікації «людина - машина», коли вербальні та невербальні знаки розкодовуються, відправник і реципієнт комунікації досягають прагматичних настанов певного типу комунікації. Третім рівнем є макрорівень АДД, де вже діє симбіоз статичних і динамічних комунікативних ознак, таких як інтерактивність, мультимедійність, інтертекстуальність, гіпертекстуальність та ін. [24, с. 17]. Доцільно не лише розглядати АДД у монологічній формі вираження або діалогічній, а й залучати методику глобалістичного, багаторівневого, лінгвоматематичного та лінгвосеміотичного аналізу.

Вербальна актуалізація АДД є такою: реалізуються основні цілі, до яких насамперед належать стратегії комунікативного впливу, подання запиту від людини до машини та його подальше кодування для "розуміння» машиною, а також інтерпретація отриманого повідомлення від машини. Для реалізації другорядних цілей, які передбачають досягнення успіху шляхом розвитку мовленнєвої діяльності представників соціальної групи англомовного дигітального дискурсу, існують допоміжні тактики та стратегії - ресурси інформування (електронні бібліотеки, Інтернет-ресурси, довідники 3 мов програмування, списки основних команд, приклади обробки природної мови, соціальні мережі і т. ін.); стратегії подання інформації та стратегії отримання інформації [23, с. 111].

Стратегіï подання інформаиії в АДД розроблено для зосередження уваги адресата на певній інформації. Розмитість меж між мовним і немовним модусом репрезентації інформації у АДД $є$ досі недослідженим аспектом. 3 одного боку, тактики подання інформації в АДД направлені на візуальну активацію перцепції нової інформації людиною, але для машини необхідне чітке завдання команд $\mathrm{i}$ чітке прописування алгоритмів, однак мовне повідомлення людини має також вдосконалюватися 3 погляду застосування лінгвальних засобів англійської мови. Дія принципу економії мовних зусиль може слугувати для утворення та комбінаторики вербальних і невербальних засобів у АДД (рис. 2).

\# def IsPalindrom ( $\mathrm{s}$ ):

if len $(\mathrm{s})<=1$ : return True

return $\mathrm{s}[0]==\mathrm{s}[$ len $(\mathrm{s})-1]$ and IsPalindrom

(s [1: len ( s ) -1])

\section{Рис. 2. Верифікація паліндрому на МП Python}

Тактика отримання інформачї̈ передбачає отримання інформації як адресатом (людиною або машиною), так і адресантом (людиною або машиною). Адресат АДД отримує інформацію з різноманітних джерел. Першим джерелом для адресата виступають повідомлення від людини або статичні команди [27]. При спілкуванні людини 3 машиною $є$ місце для образності, емоційності. Людина за певних повідомлень чинить вплив на машину, яка, у свою чергу також має приклади створення текстів команд або англомовних текстів сугестивного впливу, що належать до елементів впливу на читача [2, с. 8-14; 28].

Макротекст АДД, в нашому випадку англомовні тексти інструкцій до МП, тексти безпосередньо 
МП, тексти спілкування між машиною і людиною, мультимодальні тексти спілкування між людиною й анімованим розмовним агентом тощо, $є$ не просто замкнутою, цілісною системою, але і системою динамічною. Динаміку тексту, на думку А.Г. Баранова, створюють функціонально-прагматичні поля, котрі $є$ основними макроструктурами тексту [5]. До розряду функціонально-прагматичних меж тексту, які прив'язують його до дійсності та можливостей світу, висловлюють ставлення автора до цього світу, його суб'єктивні установки.

Безособове спілкування у межах інституційного дискурсу не $є$ широко розповсюдженою рисою, однаку межах АДД тексти МП є тією самою безособовою площиною спілкування, без якої неможливим було би спілкування людини та машини та його варіації. Отже, машина є агентом у межах інституційного дискурсу АДД.

Лінгвосеміотичний базис АДД виражено певними семантичними єдностями: один із компонентів позначає ознаку, певний зміст, а інший символічно виражає їі. Висловлюючи уточнену характеризацію об'єкта (у процесі кодування вихідного англомовного повідомлення), він детермінує наукову новизну англомовного дигітального дискурсу.

\section{Параметри АДТП}

Як підкреслює Т.В. Мілевська, текст можна вважати проміжною стадією дискурсу, якщо під дискурсом розуміти сукупність мовленнєвих і міркувальних дій обох комунікантів. Тоді текст як об'єктивно існуючий факт дійсності може розглядатися як продукт - результат дискурсу [16]. Подібне розмежування зустрічаємо й у В.С. Чернявської. У її розумінні текст є компонентом - необхідною, базовою, але тільки частиною дискурсу; це формально завершена структура, що виникла внаслідок комунікативно-когнітивного процесу - дискурсу. Дискурс - це мовне вираження суспільної практики в іiі різних комунікативних сферах; впорядковане і систематизоване особливим чином використання мови, за якою стоїть особлива - соціально-, ідеологічно-, культурно-, історично-зумовлена ментальність [24, с. 230].

Якщо текст розглядають як комплекс висловлювань, пов'язаних одне 3 одним текстуально, то дискурс постає як інтегративна сукупність текстів, звернених до однієї спільної теми, які функціонують у межах однієї і тієї самої комунікативної сфери (політичний дискурс, рекламний дискурс і т. д.). Дослідження англомовного дигітального дискурсу (АДД), таким чином, акцентує увагу на тому, які особливості комунікативно-мовленнєвої діяльності та якою мірою впливають на певне використання мови в текстовій системі. Через текстові характеристики дискурсивного рівня виявляються культурно-історичні, соціальні, ідеологічні, когнітивні форми взаємодії автора тексту і читача.

Отже, в сучасній науковій парадигмі текст $\epsilon$ вихідною точкою, фокусом, через призму котрого розглядаються різні аспекти людської діяльності, перше місце серед яких належить соціальному і когнітивному аспекту. Текст як одиниця, що реалізує в собі повідомлення, яке передається в ході мовленнєвого акту, виділяється в самостійний об'єкт дослідження прагмалінгвістики.

Надалі текст розглядатиметься як продукт, організований у межах ознак певної системи, до числа яких належать зв'язність і цілісність. Текст створюється і сприймається як єдність; текст інтегрує сенс його складників і сенс зв'язку цих складників. Для створення і розуміння тексту важливі засоби актуалізації контексту і врахування комунікативного досвіду реципієнта тексту [14].

Поняття «текст» $є$ мовним відображенням наукової абстракції, що відображає типові властивості різних комунікативних ситуацій з урахуванням сприйняття їх людиною (користувачем ПК, автором англомовного повідомлення) та інтерпретації у мовній формі задля типологізації наукового пізнання об'єкта та його інтерпретацій машиною (чат-ботом).

Таблиця 1

Функційні характеристики учасників АДД (людини та машини)

\begin{tabular}{|c|c|c|}
\hline Характеристики & Людина & Машина \\
\hline Здатність інтегрувати різноманітні елементи в єдину систему & Виражена & Обмежена \\
\hline Здатність до передбачення певних подій & Висока & Обмежена \\
\hline Здатність до вирішення нечітко сформульованих задач & Висока & Обмежена \\
\hline Здатність до розпізнавання зовнішніх ситуацій & Висока & Обмежена \\
\hline Здатність орієнтуватися у часі та просторі & Виражена & Обмежена \\
\hline Діапазон способів обробки інформації & Широкий & Обмежена \\
\hline Здатність формувати образи зовнішнього світу & Виражена & Відсутня \\
\hline Здатність генерувати ідеї & Наявна & Відсутня \\
\hline Тривалість безперервної роботи & Незначна & Велика \\
\hline Точність і швидкість обчислень & Незначна & Велика \\
\hline Об'єм оперативної пам'яті & Обмежений & Значний \\
\hline Здатність до узагальнення & Наявна & Обмежена \\
\hline Здатність до навчання & Висока & Низька \\
\hline
\end{tabular}


АДД $є$ більш індивідуалізованою актуалізацією типової текстової моделі у вигляді іiі лінгвосеміотичного варіанту. Якщо розглядати репрезентацію команд у АДТП, то можна говорити про певний англомовний текст, створений для передачі інформації від людини до машини, який вербалізує індивідуалізовані репрезентації інформаційного повідомлення автором за допомогою «спеціального коду».

Можливо стверджувати про представлення АДТП у вигляді особливої соціальної даності, результату мовленнєвої діяльності представників певної лінгвокультурної спільноти та визначити суб'єктами АДТП представників певних соціальних груп і технічних суб'єктів (чат-ботів) [26]. Основою АДТП буде двовекторна спрямованість: текстуальний аналіз (тобто структурно-семантичний аналіз на всіх рівнях мов програмування, виражених англомовними засобами), а також контекстуальний аналіз (макро(вертикальний) або мікро- (горизонтальний) аналіз). Тексти АДТП (опис команд мовами програмування та із залученням англомовних засобів) можна розглядати як результат уявного (віртуального) комунікативного акту. Під час породження та сприйняття тексту використовується не тільки знання мови, але й певний лінгвоматематичний континуум, на якому і виникають комунікативні акти між людиною та машиною. Можна стверджувати, що під час створення певного запиту «спостерігається особлива стратегія відбору найбільш значеннєвої інформації, значимої у цьому контексті та для цих комунікантів» [12]. Машина кодує вербальні символи, видає вже певний результат сприйняття спеціальної інформації та становить сутність уявного (віртуального) комунікативного акту, репрезентованого у тексті.

Якщо звернутися до мови програмування Python, то можна говорити про певну організацію тексту, структуру, в якій існує «тіло тексту» та смисл, який у процесі інтерпретації «озвучує» текст і зливається 3 його «енергією». Текст не $є$ лише словесною кон- струкцією - це, за С.В. Михайловим, «вторинна моделююча система», структура якої виходить за вербальні межі, надбудовується над «природною» мовою [15, с. 40]. Саме таке твердження корелює із літерно-цифровими засобами АДТП.

Певні об'єднані тексти, або тексти в тексті, - це коли інструкції з МП інтегрують як прописану програму, так і коментар до неї [29]:

Існують два рівні тексту: поверхневий і глибинний $[15$, с. 34]. На глибинному рівні передається імпліцитна інформація, яка визначає фактуальну, диктуючи вибір мовних засобів, забезпечуючи цілісність і зв'язність тексту. Вона є кодованим вираженням англомовної інформації, яка подається учасником АДТП. Конституенти АДТП містять складні візуально-графічні, символічні структури, що є специфічним прийомом компактного впорядкування інформації. Глибинні й асоціативні зв'язки встановлюють взаємовідносини між знаками, знаковими системами та потребують розгляду різноманітних аспектів організації лінгвосеміотичного простору текстів.

I.P. Гальпєрін виділяє змістово-фактуальну, змістово-концептуальну та змістово-підтекстну - «приховану інформацію, витягнуту зі здатності одиниць мови породжувати асоціативні та конотативні значення, а також завдяки здатності речення всередині прирощувати смисли» [9, с. 28]. Звертаючись до такого тлумачення дослідника, можливо говорити про те, що тексти базисного рівня АДТП(коди мовами програмування та кодовані ними тексти) інтегрують та інтерпретують усі три типи інформації. Спрямованість текстів АДТП на реципієнта (людину або машину) є основною причиною кодування тексту. Із цього випливає його двоплановість, тобто кожний текст містить смислову складову частину, кодовану засобами англійської мови та семіотичною репрезентацією у мовах програмування. Коли йдеться про тексти повідомлень, надісланих від відправників до реципієнтів, можна говорити про їхню насичену

def getWords (): «f= open("words.txt","r")

words $=$ f.readline ()$\cdot$ split ()

\#NOTE: readline (Oreturns a string, while readlines () returns a list.

\section{KOMEHTAP}

\#Also, split() works only on a string, NOT on list, and returns a list.

\section{KOMEHTAP}

return words

\# To call a function, you can do the following, for example: KOMEHTAP

words $=$ getWords ()

print words

Рис. 3. Приклад тексту МП Python 
інформативність, де спрацьовує інформативний регістр. Цей тип регістру відповідає за повідомлення про факти, події, властивості, абстрактні від конкретної діяльності, але інтегровані в англомовне повідомлення відправника, направлене до машини, однак специфікою побудови інформативного регістру є такий ряд логічних дій: думка - репрезентація думки - вербальні / невербальні засоби - кодування повідомлення до машини - відповідь машини.

Тексти АДТП містять зафіксовані загальні, сутнісні ознаки наукової комунікації й об'єктивні та потенційні ознаки наукового тексту. Типова структура наукового тексту вживається як базова модель наукової комунікації, забезпечуючи взаєморозуміння комунікантів (людини та машини), і є підтипом текстів наукового дискурсу [8, с. 78].

АДТП є більш індивідуалізованою актуалізаиією типової текстової моделі у вигляді ї̈ лінгвосеміотичного варіанту. Якщо розглядати репрезентацію команд у АДТП, то можна говорити про певний англомовний текст, створений для передачі інформації від людини до машини, що вербалізує індивідуалізовані репрезентації інформаційного повідомлення автором за допомогою «спеціального коду». Пропонується співвідносити параметри конституентів АДТП із інтеракційною комунікативною моделлю дискурсу. Головним принципом інтеракційної моделі $\epsilon$ взаємодія, розміщена за соціально-культурних умов [4, с. 136-137]. У процесі комунікації інформація не транслюється і не констатується, а демонструється через смисли, які не обов'язково мають бути розпізнані й інтерпретовані реципієнтом. Ця модель особливо актуальна для АДД, у котрому будь-яка дія, бездіяльність, мова, мовчання можуть виявитися комунікативно-значеннєвими (смайли, абревіатури ін.). Таким чином, зазначено, що в АДТП відбивається спрямованість на активне сприйняття реципієнта, без його участі в єдиному процесі демонстрації смислів, особливо у процесі їх інтерпретації.

Висновки i перспективи подальших розробок. У дослідженні АДД визначається як письмовий процес і результат взаємодії учасників комунікації, опосередкованої комп'ютерними технологіями, або тематично 3 ними співвіднесеними текстами на МП та їх лінгвосеміотичним базисом, режимами їх кодування - декодування у процесі комунікації «людина - людина», «людина - машина», «людина - машина - людина» та їхніх варіацій. АДТП визначається як письмовий результат взаємодії учасників АДД, відображений у текстах, що опосередковують комунікацію «людина - людина», «людина - машина», «людина - машина - людина» та їхніх варіацій. АДТП безпосередньо або опосередковано представлений лінгвосеміотичним базисом мов програмування, англомовним базисом i прописаними режимами його кодування - декоду- вання. Найголовнішою визначною рисою АДД є його «дигіталізована соціальність». Прописування певних кодів об'єктно-орієнтованими мовами програмування та їх вербалізація засобами англійської мови свідчить про розширення меж такого інформаційного та технократичного простору. Перспективу подальших наукових розвідок вбачаємо на перетині інноваційних технологій і наук (прикладної лінгвістики, математичної лінгвістики, корпусної лінгвістики, робототехніки, штучного інтелекту тощо), кореляції англомовного універсального базису 3 опосередкуванням медіації глобального технократичного суспільства.

\section{ЛІТЕРАТУРА}

1. Аликаев Р.С. Язык науки в парадигме современной лингвистики. Нальчик : Эль-Фа, 1999. $317 \mathrm{c}$.

2. Андрейчук Н.I. Потенціал лінгвосеміотичної інтерпретації для розвитку перекладознавчих студій. Записки з романо-германської філолоziï. 2015. Вип. 1. С. 8-14.

3. Арнольд И.В. Основы научных исследований в лингвистике : учебное пособие. Москва : Высшая школа, 1991. 140 с.

4. Арутюнова Н.Д. Предложение и его смысл. Москва : Едиториал УРСС, 2005. 384 с.

5. Баранов А.Н. Введение в прикладную лингвистику : учебное пособие. Москва : ЛКИ, 2007. C. $58-70$.

6. Бондалетов В.Д. Социальная лингвистика. Москва : Просвещение, 1987. С. 141-159.

7. Бондаренко С.В. Картина світу і дискурс: peaлізація дуальної природи людини. Дискурс як когнітивно-комунікативний феномен. Харків : Константа, 2005. С. 36-64.

8. Гальперин И.Р. Текст как объект лингвистического исследования. Москва : КомКнига, 2006. $144 \mathrm{c}$.

9. Гальперін I.P. Текст як об'єкт лінгвістичного дослідження. Москва : Наука, 1981. 139 с.

10. Каменская О.Л. Текст и коммуникация. Москва : Высшая школа, 1990. 152 с.

11. Карасик В.И. О типах дискурса. Язылковая личность: институциональный и персональный дискурс : сборник научных трудов. Волгоград : Перемена, 2000. 52 с.

12. Касумова М.Ю. Компьютерный дискурс как полиаспектная разновидность речи. URL: http://rusistica.ru/articles.php?article_id=5 (дата звернення 16.03.2021).

13. Латышев Л.К. Курс перевода (эквивалентность перевода и способы ее достижения). Москва : Международные отношения, 1981. $247 \mathrm{c}$.

14. Макаров М.Л. Основы теории дискурса. Москва : ИТДГК «Гнозис», 2003. 280 с. 
15. Михайлов С.В. Особенности развития информационно-коммуникативной среды современного общества. Актуальные проблемы теории коммуникации. Санкт-Петербург : Изд-во СПбГПУ, 2004. С. 34-52.

16. Мілевська Т.В. Моделі інноваційного розвитку економіки. Бізнес Інформ. 2012. № 7. С. 44-47.

17. Олянич А.В. Презентационная теория дискурса: монография. Москва:Гнозис, 2007.407 с.

18. Степанов Ю.С. Альтернативный мир, дискурс, факт и принцип причинности. Язык и наука конца XX века. Москва : РГГУ, 1995. $432 \mathrm{c}$.

19. Чернявская В.Е. Лингвистика текста: Поликодовость, интерпретация, интердискурсивность : учебное пособие Москва : Книжный дом «ЛИБРОКОМ», 2009. $284 \mathrm{c.}$

20. Чернявская В.Е. Лингвистика текста. Лингвистика дискурса : учебное пособие. Москва : Флинта, 2013. 208 с.

21. Чернявская В.Е. От анализа текста к анализу дискурса. Текст и дискурс: традиционный и когнитивно-функциональный аспекты исследования. Рязань, 2002. С. 230-232.

22. Шейгал Е.И. Семиотика политического дискурса. Москва : Гнозис, 2004. 326 с.

23. Allen P. Information Culture is in Need of Development. Network News, 2001. URL: http:// www.fundinguniverse.com/company-histories/ Microsoft-Corporation-Company-History.html (дата звернення: 16.03.2021).

24. Babulak E. Informatics and Social Impact of IT on Society. 2013. URL: https://www.researchgate.net/publication/275771554_Informatics and_Social_Impact_of IT_on_Society (дата звернення: 04.03.2021).

25. Bandhakavi A., Wiratunga N., Massie S. Lexicon generation for emotion detection from text. IEEE Intelligent Systems. 2017. Vol. 32 (1). P. 102-108.

26. Creating a Civil Discourse on the Web. Daily Herald. 2011. URL: http://www.publicconversations.org/blog/civil-discourse-meet-internetinternet-meet-civil-discourse (дата звернення: 12.03.2021).

27. Crystal D. Language and the Internet. Cambridge : Cambridge University Press, 2001. 272 p.

28. Popova Z.D., Sternin I.A. The notion of concept in linguistic studies. Voronezh, 1999. $30 \mathrm{c}$.

29. Schwarz J., Blunsom P. The NarrativeQA Reading Comprehension Challenge. Transactions of the Association for Computational Linguistics. 2018. Vol. 6. P. 317-328.

\section{REFERENCES}

1. Alikaev, R. (1999) The language of science in the paradigm of modern linguistics. [Yazyik nauki $\mathrm{v}$ paradigme sovremennoy lingvistiki]. Nalchik: El-Fa, $317 \mathrm{p}$.

2. Andreychuk, N. (2015) The potential of linguosemiotic interpretation for the development of translation studies [Potentsial lingvosemiotichnoii Interpretatsii dlya rozvitku perekladoznavchih studiy]. Notes on Romano-Germanic philology, Issue 1, pp. 8-14.

3. Arnold, I. (1991) Fundamentals of scientific research in linguistics [Osnovyi nauchnyih issledovaniy v lingvistike]: textbook. Moskow: Higher school, $140 \mathrm{p}$

4. Arutyunova, N. (2005) The sentence and its meaning [Predlozhenie i ego smyisl]. Moskow: Editorial URSS, $384 \mathrm{p}$.

5. Baranov, A.(2007) Introduction to applied linguistics [Vvedenie $\mathrm{v}$ prikladnuyu lingvistiku]: textbook. allowance. Moskow: LKI, pp. 58-70.

6. Bondaletov, V. (1987) Social linguistics [Sotsialnaya lingvistika]. Moscow: Enlightenment, pp. 141-159.

7. Bondarenko, E. (2005) Picture of the world and discourse: the realization of the dual nature of man. Discourse as a cognitive-communicative phenomenon [Kartina svitu i diskurs: realizatsiya dualnoYi prirodi lyudini. Diskurs yak kognitivno-komunikativniy fenomen]. Kharkiv: Konstanta, pp. 36-64.

8. Galperin, I. (2006) Text as an object of linguistic research [Tekst kak ob'ekt lingvisticheskogo issledovaniya]. Moskow: KomKniga, 144 p.

9. Halperin, I. (1981) Text as an object of linguistic research [Tekst yak ob'ekt lingvistichnogo doslidzhennya]. Moscow: Nauka, 139 p.

10. Kamenskaya, O. (1990) Text and communication [Tekst i kommunikatsiya]. Moscow: Higher School, $152 \mathrm{p}$.

11. Karasik, V. (2000) On the types of discourse. Linguistic personality: institutional and personal discourse [O tipah diskursa. Yazyikovaya lichnost: institutsionalnyiy i personalnyiy diskurs]. Volgograd: Peremen, $52 \mathrm{p}$.

12. Kasumova, M. (2019) Computer discourse as a multifaceted type of speech [Kompyuternyiy diskurs kak poliaspektnaya raznovidnost rechi]. Retrieved from: http://rusistica.ru/articles. php?article id=5 (accessed 16.03.2021).

13. Latyshev, L. (1981) Translation course (translation equivalence and ways to achieve it) [Kurs perevoda (ekvivalentnost perevoda i sposobyi ee dostizheniya)]. Moskow: Mezhdunarodnye otnosheniya, $247 \mathrm{p}$.

14. Makarov, M. (2003) Fundamentals of discourse theory [Osnovyi teorii diskursa]. Moskow: ITDGK “Gnosis", $280 \mathrm{p}$.

15. Mikhailov, S. (2004) Features of the development of information and communication environment 
of modern society. [Osobennosti razvitiya informatsionno-kommunikativnoy sredyi sovremennogo obschestva]. Actual problems of communication theory. Sankt-Peterburg: Izd-vo SPbGPU, pp. 34-52.

16. Milevskaya, T. (2012) Models of innovative economic development [ModelI InnovatsIynogo rozvitku ekonomIki]. Business Inform, № 7, pp. 44-47.

17. Olyanich, A. (2007) Presentation theory of discourse: a monograph [Prezentatsionnaya teoriya diskursa: monografiya]. Moskow: Gnosis, $407 \mathrm{p}$.

18. Stepanov, Y. (1995) Alternative world, discourse, fact and the principle of causality [Alternativnyiy mir, diskurs, fakt i printsip prichinnosti]. Language and science of the end of the XX century. Moskow: RGGU, $432 \mathrm{p}$.

19. Chernyavskaya, V. (2009) Linguistics text: Polycodation, interpretation, interdiscursivity: textbook [Lingvistika teksta: Polikodovost, interpretatsiya, interdiskursivnost]. Moskow: Book House "LIBROCOM", 284 p.

20. Chernyavskaya, V. (2013) Linguistics of the text. Linguistics of discourse: textbook [Lingvistika teksta. Lingvistika diskursa]. Moskow: Flinta, 208 p.

21. Chernyavskaya, V. (2002) From text analysis to discourse analysis. Text and discourse: traditional and cognitive-functional aspects of research [Ot analiza teksta $\mathrm{k}$ analizu diskursa. Tekst $\mathrm{i}$ diskurs: traditsionnyiy i kognitivno-funktsionalnyiy aspektyi issledovaniya]. Ryazan, pp. 230-232.

22. Sheigal, E. (2004) Semiotics of political discourse. Moskow: Gnosis, 326 p.

23. Allen, P. (2001) Information Culture is in Need of Development. Network News. Retrieved from $\mathrm{http}: / / \mathrm{www}$.fundinguniverse.com/company-histories/Microsoft-Corporation-Company-History. html (accessed 16.03.2021).

24. Babulak, E. (2013) Informatics and Social Impact of IT on Society. Retrieved from: https://www. researchgate.net/publication/275771554_Informat ics_and_Social_Impact_of_IT_on_Society

25. Bandhakavi, A., Wiratunga, N., Massie, S. (2017) Lexicon generation for emotion detection from text. IEEE Intelligent Systems, Vol. 32 (1), P. $102-108$

26. Creating a Civil Discourse on the Web. Daily Herald (2011). Retrieved from: http://www.publicconversations.org/blog/civil-discourse-meet-internet-internet-meet-civil-discourse (accessed 12.03.2021).

27. Crystal, D. (2001) Language and the Internet. Cambridge : Cambridge University Press, $272 \mathrm{p}$.

28. Popova, Z., Sternin, I. (1999) The notion of concept in linguistic studies. Voronezh, $30 \mathrm{p}$.

29. Schwarz, J., Blunsom, P. (2018) The NarrativeQA Reading Comprehension Challenge. Transactions of the Association for Computational Linguistics, Vol. 6, P. 317-328. 